\title{
A spectroscopic study of the impact of arsenic speciation on arsenic/phosphorous uptake and plant growth in tumbleweed (Salsola kali)
}

\author{
Guadalupe de la Rosa ${ }^{\dagger, \ddagger}$, Jason G. Parsons $§$, Alejandro Martinez-Martinez ${ }^{\S} \#$, Jose R. \\ Peralta-Videa§, and Jorge L. Gardea-Torresdey $\dagger, \S,{ }^{*}$ \\ $\uparrow$ University of Texas at El Paso, Environmental Science and Engineering Ph.D. Program 500 W. University \\ Ave., El Paso, Texas, 79968 \\ $\S$ University of Texas at El Paso, Department of Chemistry 500 W. University Ave., El Paso, Texas, 79968 \\ \# Instituto de Ciencias Biomédicas, Universidad Autónoma de Ciudad Juárez, Cd. Juárez, Chihuahua, México
}

\begin{abstract}
This manuscript reports the toxic effects of $\mathrm{As}_{2} \mathrm{O}_{3}$ (arsenic trioxide) and $\mathrm{As}_{2} \mathrm{O}_{5}$ (arsenic pentoxide) on S. kali, as well as the arsenic and phosphate uptake, and arsenic coordination within plant tissues. Plants were germinated and grown for 15 days on a Hoagland modified medium containing either $\mathrm{As}(\mathrm{III})$ (arsenic trioxide) or As(V) (arsenic pentoxide). Subsequently, the seedlings were measured and analyzed using ICP-OES and XAS techniques. Plants stressed with $2 \mathrm{mg} \mathrm{L}^{-1}$ of whichever As (III) or As(V) concentrated $245 \pm 19,30 \pm 1$, and $60 \pm 3 \mathrm{mg} \mathrm{As} \mathrm{kg}^{-1} \mathrm{~d}$. wt, or $70 \pm 6,10 \pm 0.3$, and $27 \pm 3 \mathrm{mg} \mathrm{As} \mathrm{kg}{ }^{-1} \mathrm{~d}$. wt in roots, stems, and leaves, respectively. Arsenate was less toxic and more As translocation occurred from the roots to the leaves. All treatments reduced $\mathrm{P}$ concentration at root level; however, only $\mathrm{As}(\mathrm{V})$ at 2 and $4 \mathrm{mg} \mathrm{L}^{-1}$ reduced $\mathrm{P}$ concentration at leaf level. Regardless the arsenic species supplied to the plants, arsenic was found in plant tissues as As(III) coordinated to three sulfur ligands with an interatomic distance of approximately $2.25 \AA$.
\end{abstract}

\section{Keywords}

As uptake; As reduction; Tumbleweed; desert plant; non-mycorrhizal association; XAS; ICP-OES

\section{Introduction}

The presence of arsenic in soils and waters provides a route for human and animal exposure to this element. Thus, the restoration of arsenic polluted environments becomes an important task to reduce health risks. Traditional methods to remediate arsenic laden soils are expensive and the soils still have to be disposed of after treatment $(1,2)$. An emerging technology for the remediation of soils and waters is phytoremediation, defined as the use of plants for cleaning or reducing the toxicity of contaminated environments (3). Phytoremediation technologies include phytorestoration, which is the revegetation of barren soils to avoid the dispersion of contaminated soil particles (3). Phytorestoration of arsenic contaminated lands is sometimes complicated since many polluted areas lack mycorrhizal species, thus reducing the

\footnotetext{
*Corresponding author: Tel.: (915) 747-5359; Fax: (915) 747-5748; jgardea@utep.edu.

*Present address: Facultad de Química, Universidad de Guanajuato, Col. N. Alta s/n, C.P. 36050, Guanajuato, Gto., México
} 
establishment of mycorrhizal dependent plants (4). In addition, few plant species are tolerant to elevated As concentrations and low nutrient availability (5).

Several plants with the ability to uptake heavy metals or toxic chemicals have been described in the literature (6-12). However, in the case of arsenic, only one hyperaccumulator plant has been reported to date (8). Even when several species including Holcus lanatus and Basin wildrye have demonstrated tolerance to this element $(5,13)$, they form mycorrhizal association. In this context, the identification of plant species suitable for phytorestoration and/or phytoextraction of As from polluted soils with or without mycorrhizal association is especially important. In addition, the understanding of the mechanisms of tolerance and hyperaccumulation is of paramount importance since this will lead to the improvement of phytoremediation techniques.

Although a number of metal contaminated sites are located in desert areas, to our knowledge, little is known about the toxicity and uptake of As by desert plant species. Consequently, the information about the mechanisms of As accumulation in these plants is limited. Several techniques (14-19) including X-ray absorption spectroscopy (XAS) have been used to determine the speciation and coordination of arsenic taken up by plants $(15,20,21)$. In this study, Salsola kali, a drought tolerant bush, which does not form mycorrhizal association and that has proven beneficial for the restoration of disturbed sites (22), was studied for its ability to uptake arsenic. Arsenic and phosphorus were determined in plants treated with arsenic trioxide and arsenic pentoxide. In addition, XAS studies were performed to determine the oxidation state and the coordination environment of the arsenic within the plants. Important data is been provided herein since tumbleweed may be used in the revegetation of disturbed sites contaminated with arsenic.

\section{Materials and Methods}

\section{Plant growth}

A modified Hoagland nutrient medium was used to germinate and grow seedlings of tumbleweed in different concentrations of $\mathrm{As}_{2} \mathrm{O}_{3}$ (arsenic trioxide, $\mathrm{As}(\mathrm{III})$ ) and $\mathrm{As}_{2} \mathrm{O}_{5}$ (arsenic pentoxide, $\mathrm{As}(\mathrm{V})$ ). The nutrient medium prepared as described by Peralta et al. (23), was amended with either $\mathrm{As}(\mathrm{III})$ or $\mathrm{As}(\mathrm{V})$ to obtain concentrations of $0,1,2$, and $4 \mathrm{mg} \mathrm{L}^{-1}$ As. After the $\mathrm{pH}$ was adjusted to 5.8 , the agar was added $(0.5 \% \mathrm{w} / \mathrm{v})$ and the media was poured into $250 \mathrm{~mL}$ jars and sterilized. Approximately 40 seeds of tumbleweed previously disinfected with an antibiotic/antimycotic solution (A 9909, Sigma, St Louis, MO, USA) were planted for every treatment. The jars were placed under a $12 \mathrm{~h}$ photoperiod with a photon irradiance of $39.5 \mu \mathrm{mol} \mathrm{m} \mathrm{m}^{-2} \mathrm{~s}^{-1}$ and a temperature of $25^{\circ} \mathrm{C}$. The seed germination was evaluated after four days and the uptake study was performed after 15 days, at which time the plants were removed from the growth media and the root and shoot length was measured and kept for further evaluation. Every treatment was in triplicate for statistical purposes.

\section{Determination of $\mathbf{A s}(\mathrm{III})$ and $\mathrm{As}(\mathrm{V})$ effect on plant growth}

Complete plants were rinsed using $0.01 \mathrm{M} \mathrm{HNO}_{3}$, and washed with DI water (deionized water). Afterwards, the root and shoot length of 10 plants per replicate/treatment were measured and separated into roots, stems, and leaves. The samples were then oven dried for $72 \mathrm{~h}$ at $60^{\circ} \mathrm{C}$ to avoid As volatilization (24), and the dry mass was recorded. Data were statistically analyzed to determine the effect of the treatments on plant growth and biomass accumulation.

\section{Digestion}

Oven dried samples were weighed and acid digested to destroy organic matter and to solubilize the elements for chemical quantification. Digestion was performed using $5.0 \mathrm{~mL}$ trace pure 
$\mathrm{HNO}_{3}$ via microwave assistance and following EPA method 3051 with minor modifications (25). A temperature of $120^{\circ} \mathrm{C}$ was used in order to avoid As volatilization (26). The digested samples were then diluted to a final volume of $10 \mathrm{~mL}$ using deionized water.

\section{ICP-OES analysis}

Total As and P in the digested samples were determined using an ICP-OES Optima 4300 DV (Perkin Elmer, Shelton, CT, USA). Analyses were performed under optimized conditions according to EPA method 200.7 (27) with minor modifications. The wavelengths 197.197 and $178.221 \mathrm{~nm}$ used to determine the total As and P, respectively, were selected based on correlation coefficients and detection limits. Calibration curves (with correlation coefficients $\geq 0.9999$ ) were obtained using the blank and four concentrations of each element. Spiked control samples were used every 10 samples for QA/QC (Quality assurance/quality control).

\section{Statistical Analyses}

One-way analysis of variance (ANOVA), Tukey's HSD (honestly significant difference) test, t-test analyses and Pearson correlation coefficients were used as statistical tools (SPSS 11.0, Chicago, IL).

\section{XAS sample preparation}

Plant tissues were immersed in liquid nitrogen for $45 \mathrm{~min}$ and lyophilized at $-45^{\circ} \mathrm{C}$ and $69 \times$ $10^{-3}$ Mbar pressure (LabConco Freeze Zone 4.5, Kansas City, MO, USA). After lyophilization, the samples were ground into a fine powder and packed into $1 \mathrm{~mm}$ aluminum sample plates with Kapton ${ }^{\circledR}$ tape windows. Samples were analyzed at the Stanford Synchrotron Radiation Laboratory (SSRL, Menlo Park, CA, USA).

\section{XAS data acquisition}

The samples were run on Beamline 7-3 at SSRL using a 13 element Ge detector (Canberra Industries, Meriden, CT, USA) and an Oxford liquid helium cryostat (Oxford Instruments, Livingstone, UK) to reduce thermal disorder in the samples. The beamline conditions were as follows: energy of $60 \mathrm{~mA}$, beam current of $2.3 \mathrm{GeV}$, and a $\mathrm{Si}(220, \phi 90)$ double crystal monochromator. The samples (ran in fluorescence mode) and model compounds (ran in transmission mode) were scanned twice to reduce noise, and verify the obtained spectra. Both the samples and model compounds were run using an internal As(0) foil for calibration purposes. The model compounds were ground using a mortar and pestle until a homogenous mixture was obtained. The dilution of the model compounds was performed using a predetermined mass of boron nitride to obtain a 1 absorption unit change across the absorption edge.

\section{XAS data analysis}

The XAS data analyses were performed using the WinXAS software and standard methods (28). The samples were averaged and calibrated using a second degree derivative of the internal arsenic foil (energy of $11.898 \mathrm{keV}$ ). The pre-edge region of sample spectra were background corrected using a one degree polynomial fitting and the post-edge regions were background corrected using a five degree polynomial fitting. The XANES spectra of both the model compounds and the samples were extracted from the background corrected spectra from 11.80 $\mathrm{keV}$ to $11.96 \mathrm{keV}$. The EXAFS were extracted from the background corrected spectra by first converting the spectra to $\mathrm{k}$ space, based on the energy of the photoelectron ejected from the sample. This was calculated using a second degree derivative of the individual sample and model compound absorption edges. The extracted EXAFS spectra were subsequently $\mathrm{k}$ weighted to three and Fourier transformed using a Bessel window. The back transforms of the Fourier transformed EXAFS were based on the first coordination shell of the sample spectra 
and were back-transformed and fitted using FEFF V 8.10 (The FEFF Project, University of Washington, Seattle, WA, USA). The input files for the FEFF calculations were based on crystallographic data of the model compounds input into the ATOMS software (Version 2.5, Naval Research Laboratory, Washington, DC, USA). From the FEFF output files the interatomic distances, coordination numbers, and Debye-Waller factors were calculated.

\section{Results and Discussion}

The maximum allowed concentration for arsenic in soils in the U.S.A. is of $0.4 \mathrm{mg} \mathrm{kg}^{-1}(29)$. We decided to test concentrations up to ten times that amount in order to have a worst case scenario of As toxicity and accumulation in S. kali. Thus, we tested As concentrations of 0,1 , 2 , and $4 \mathrm{mg} \mathrm{L}^{-1}$.

\section{Effect of arsenic on tumbleweed growth}

In this study, none of the treatments significantly reduced seed germination and As(V) allowed seedlings development at concentrations up to $4 \mathrm{mg} \mathrm{L}^{-1}$. However, it was found that above 2 $\mathrm{mg} \mathrm{L}^{-1}$, As(III) was lethal for tumbleweed seedlings (data not shown). Neither As(III) nor As (V) treatments reduced root and leaf biomass accumulation. For all treatments, roots mass was between $3.8 \pm 0.12$ to $5.1 \pm 0.5 \mathrm{mg}$, while the mass of the leaves ranged from $5.47 \pm 0.43$ to $6.77 \pm 0.24 \mathrm{mg}$, with no significant differences $(\mathrm{P}<0.05)$ between treatments. In terms of biomass accumulation, stem tissues were positively sensitive to $\mathrm{As}(\mathrm{V})$ but not to $\mathrm{As}(\mathrm{III})$. The mass of control stems and those treated with 1 and $2 \mathrm{mg} \mathrm{As}$ (III) $\mathrm{L}^{-1}$ were of $8.23 \pm 0.43,7.43$ \pm 0.54 , and $7.30 \pm 0.7 \mathrm{mg}$, respectively, with no significant differences $(\mathrm{P}<0.05)$. However, an increase in biomass accumulation was detected in stems of tumbleweed plants grown in As (V), presenting masses of $9.90 \pm 0.42,10.43 \pm 0.29$, and $9.17 \pm 0.32 \mathrm{mg}$ for the 1,2 , and $4 \mathrm{mg}$ As(V) $\mathrm{L}^{-1}$, respectively.

According to the results, all of the As(III) treatments used in this study significantly decreased $(\mathrm{P}<0.05)$ root and shoot elongation as compared to control and As $(\mathrm{V})$ treated plants (Figures 1a, 1b). Root elongation in plants exposed to $2 \mathrm{mg} \mathrm{As}(\mathrm{III}) \mathrm{L}^{-1}$ decreased about $50 \%$ as compared to control plants. It appears that shoots were less sensitive to As(III) levels since the elongation of this part of the plants only decreased by about $30 \%$ as compared to control shoots. However, Figure 1(b) shows an increase of about $20 \%$ in shoot length in plants treated with 1 and $2 \mathrm{mg} \mathrm{As}(\mathrm{V}) \mathrm{L}^{-1}$ as compared to control plants; such effect is called hormesis and has been observed in a variety of living organisms (30). Pearson correlation coefficients calculated for root and shoot elongation against As concentration in the media were of -0.926 and -0.8 , respectively (2-tailed, $\mathrm{P}<0.01$ ). Thus, the negative effect of As(III) on plant growth was noticeable. On the other hand, the correlation value for $\mathrm{As}(\mathrm{V})$ concentration in the media and root length was of -0.5 (2-tailed, $\mathrm{P}<0.01)$. This means that $\mathrm{As}(\mathrm{V})$ did not affect root growth as much as As(III). No significant relationship was found for shoot elongation in plants treated with As(V). According to Tu et al. (31), the As hyperaccumulator Pteris vittata L. increased its biomass when transplanted to an $\mathrm{As}(\mathrm{V})$ contaminated soil, and Carbonell-Barrachina et al. (32) found that As(V) increased the growth of S. patents and S. alterniflora plants. On the other hand, As(III) affected plant growth in Oryza sativa L. (26). None of the treatments produced chlorosis in tumbleweed seedlings.

\section{Uptake of As species by tumbleweed}

As previously explained, As(III) at $4 \mathrm{mg} \mathrm{L}^{-1}$ was lethal for tumbleweed plants. Figure 2(a) shows that plants exposed to $2 \mathrm{mg} \mathrm{As}$ (III) $\mathrm{L}^{-1}$ accumulated $245 \pm 19,30 \pm 1$, and $60 \pm 3 \mathrm{mg}$ As kg ${ }^{-1} \mathrm{~d}$. wt in roots, stems, and leaves, respectively. The lack of significant differences between As concentrations in the roots of the two As(III) treatments might indicate that tumbleweed plants reached the maximum As storage concentration when exposed to As(III). 
However, doubling the arsenic concentration in the growth media resulted in 2 and 2.5 fold the As concentration in stems and leaves, respectively. No significant differences $(\mathrm{P}<0.05)$ between the amounts of As accumulated in stems and leaves were found (one-way ANOVA, Tukey's HSD). Nevertheless, the trend indicates that the plant might possess the ability to move As from stems to leaves.

The arsenic concentration in plants stressed with $\mathrm{As}(\mathrm{V})$ is shown in Figure 2(b). The data suggest that the As concentrations in leaves were statistically higher $(\mathrm{P}<0.05)$ than the As concentrations in stems, which could indicate that As is more easily translocated from stems to leaves when supplied as As(V). According to these data, As speciation significantly affected the final concentration of this element in plant tissues. Comparing the arsenic concentration in root tissue of plants grown with $1 \mathrm{mg} \mathrm{L}^{-1} \mathrm{As}$, an 8 fold amount was found in plants treated with $\mathrm{As}(\mathrm{III})$ as compared to those grown in $\mathrm{As}(\mathrm{V})$. In addition, when As was supplied at $2 \mathrm{mg}$ $\mathrm{L}^{-1}$ level, a 3 fold and 2 fold increase in As concentration in stems and leaves, respectively, was found in plants treated with As(III) as compared to plants stressed with $\mathrm{As}(\mathrm{V})$ (Figure 2). The results presented herein differ from those reported by Aldrich et al. (33), who found a higher concentration of As in tissues of Prosopis spp. when the plants were grown in agar media containing $\mathrm{As}(\mathrm{V})$.

Assuming that all the arsenic in the agar is water soluble, the As bioconcentration factor (BF) in plants treated with $2 \mathrm{mg} \mathrm{L}^{-1}$ was about 170 and 54 for the $\mathrm{As}(\mathrm{III})$ and $\mathrm{As}(\mathrm{V})$ treatments, respectively. Even when arsenic concentrations found in $S$. kali are not as high as those reported for Chinese brake (Pteris vittata) and other fern species $(31,34)$, tumbleweed has demonstrated a better As uptake ability than other plants. For example, leaves of honey mesquite grown in an agar media containing $5 \mathrm{mg} \mathrm{As}(\mathrm{V}) \mathrm{L}^{-}{ }_{1}$ accumulated only a fifth the amount of As accumulated by tumbleweed exposed to the $4 \mathrm{mg} \mathrm{As} \mathrm{L}^{-}{ }_{1}$ treatment (32). In addition, leaves of Indian mustard plants exposed to a $250 \mu \mathrm{M}\left[18.75 \mathrm{mg} \mathrm{As}(\mathrm{V}) \mathrm{L}^{-}{ }_{1}\right]$ solution for 5 days, accumulated only a third the amount reported herein for tumbleweed leaves (14).

\section{Effect of arsenic speciation on phosphorous uptake}

The phosphorous uptake data (Table 1) show that the presence of both arsenic species in the growth media significantly $(\mathrm{P}<0.05)$ reduced phosphorous content in roots as compared to controls plants. On the other hand, no significant differences $(\mathrm{P}<0.05)$ were observed in phosphorous concentration at stem level. The presence of $\mathrm{As}(\mathrm{V})$ in the growth media significantly reduced phosphorous concentrations in leaf tissue. In plants treated with As(III), the Pearson correlation analysis (Table 2) revealed a negative relationship between As and $\mathrm{P}$ concentration in root tissue $(-0.865, \mathrm{P}<0.01,2$-tailed $)$. However, As $(\mathrm{V})$ significantly reduced phosphorous content in roots and leaves (Pearson correlation coefficients of -0.871 , and -0.739 , respectively, at $\mathrm{P}<0.01,2$-tailed). Thus, phosphorous absorption was also affected by arsenic speciation. The results indicate that more As was translocated from the As(V) medium than the As(III) growth medium (Figure 2), which may be related to the decrease in phosphorous content in leaves of plants treated with $\mathrm{As}(\mathrm{V})$. Studies have reported on the reduction on phosphate uptake in plants exposed to arsenate which indicate that arsenate uptake occurs via the phosphate system even replacing $\mathrm{P}$ in the phosphate groups of biomolecules (35-37). It has also been proposed that arsenate uptake via the phosphate system occurs in some arsenic non-tolerant plants while in tolerant plants such system might be altered (35). Therefore, in the case of $\mathrm{As}(\mathrm{V})$, it is very likely that the metalloid entered tumbleweed plants via phosphate uptake, thus reducing phosphorous concentration in roots and its subsequent transport to the leaves. 


\section{XAS Studies}

The XANES spectra of As in tumbleweed plants treated with As(V) and As(III) are displayed in Figure 3(a) and 3(b), respectively. Previous data obtained using XAS analysis (33) have shown that $84 \%$ of the $\mathrm{As}(\mathrm{V})$ supplied to the agar media remains as $\mathrm{As}(\mathrm{V})$. Thus, important amounts of $\mathrm{As}(\mathrm{V})$ should be found in plant tissues if the plants were not able to reduced it. However, the XANES of the As in plant samples (Figure 3) indicated that As(V) was reduced to As(III) and complexed to sulfur within all sections of the plant. Nevertheless, the complex formed within the plants was not $\mathrm{As}_{2} \mathrm{~S}_{3}$ as a difference in the geometry of the two different As-S complexes was observed (See Figure 1a, Supporting information). The XANES studies of the As(III) uptake by tumbleweed shown in Figure 3(b) display similar results to the uptake of the $\mathrm{As}(\mathrm{V})$ from the growth media. The absorption edge shows up at the same energy as the $\mathrm{As}_{2} \mathrm{~S}_{3}$ model compound, indicating that the coordination of arsenic in the plants is with sulfur and the arsenic is present as As(III). Similar to the XANES results of As in plant samples treated with $\mathrm{As}(\mathrm{V})$, different geometries for $\mathrm{As}(\mathrm{III})-\mathrm{S}$ complex and the $\mathrm{As}_{2} \mathrm{~S}_{3}$ compound was observed (See Figure 1b, Supporting Information).

The EXAFS fittings for As(V) taken up by tumbleweed in roots, shoots, and leaves are shown in Table 3. The results of EXAFS studies show that As(V) taken up by tumbleweed is coordinated solely to sulfur ligands. In addition, from the FEFF fittings of the absorbed arsenic (Table 3), the coordination of sulfur to the arsenic indicates that there are three sulfur back scatters at interatomic distances ranging from $2.24 \AA$ to $2.26 \AA$, very similar to the As(III) sulfide. However, the As(III) taken up and bound to the sulfur within the plants is missing the As-As coordination observed at approximately $3.2 \AA$. The transformation of the arsenic from an oxygen ligand complex to a sulfur ligand complex might mainly occur within the roots. This arsenic sulfur containing complex is found throughout the entire plant (roots, stems, and leaves) as can be observed in Table 3. The EXAFS of roots, stems, and leaves of tumbleweed treated with $\mathrm{As}(\mathrm{III})$ showed that, similar to $\mathrm{As}(\mathrm{V})$, the absorbed $\mathrm{As}(\mathrm{III})$ is found within the entire plant in a sulfur containing complex with 3 sulfur ligands at an approximate interatomic distance of $2.25 \AA$ (Table 3, see also Figure 2a, b Supporting Information).

The results presented herein showed that a complete biotransformation of both As(III) and As (V) to As-S complexes within all portions of the plants occurred, indicating that this is a specific response of tumbleweed to arsenic contamination. Pickering et al. (14) were able to identify the arsenate present in the xylem sap of $B$. juncea plants exposed for 5 days to a $250 \mu \mathrm{M}$ arsenate treatment. Since the XAS data of this study were collected at the end of the experimental period and the results indicated the presence of solely As(III)-S chelated compounds in all plant parts, it is possible that in the first days of treatment, part of the $\mathrm{As}(\mathrm{V})$ was transported in the arsenate form and was subsequently reduced to the As(III)-S complexes. However, further studies are needed in order to corroborate this hypothesis.

It is known that inorganic As(III) is more toxic than inorganic $\mathrm{As}(\mathrm{V})$ mainly because $\mathrm{As}(\mathrm{III})$ readily binds to sulfur and nitrogen groups disrupting normal functions of proteins and enzymes $(38,39)$. Thus, it is expected that As(III) rapidly reacts with proteins and enzymes present in the plasma membrane affecting structural integrity. Important data for the uptake and resistance to arsenic in S. cerevisiae has been obtained (40). However, the uptake mechanism, transport, and biotransformation of arsenic species in plants are still unclear. Furthermore, As(III) should be taken up and transformed in a different pathway than $\mathrm{As}(\mathrm{V})$. As mentioned before, part of the As(III) absorbed by the roots probably reacts with proteins and enzymes. In S. cerevisiae, the FPS1 gene encodes a membrane protein similar to bacterial and mammalian aquaglyceroporin involved in arsenite uptake (41). Thus, it is very likely that the transport of As(III) through plasmalemma in tumbleweed plants be facilitated by a type of aquaglyceroporin, similar to the one that has been found in loblolly pine (Pinus taeda, gi 15777892) and in common tobacco (Nicotiana tabacum, gi 4584428). In the biotransformation 
of As-O to As-S, it is very possible that low molecular weight thiols (including glutathione) react with $\mathrm{As}(\mathrm{III})$ to form complexes of the type $\mathrm{As}(\mathrm{R}-\mathrm{S})_{3}$. The resulting complex might be stored in vacuoles and/or transported to stems and leaves in a much less toxic form of As(III). Our hypothesis is based on Ghosh et al. (40) who reported that in S. cerevisiae the As(III) resistance includes extrusion and vacuolar sequestration (in the form of the As-glutathione 3 complex). These two mechanisms in this yeast are mediated by the ACR (arsenic compounds resistance), and the YCF1 gene products. Even though the YCF gene has been found in plants including Arabidopsis thaliana, Pinus tunbergii, Zea mays, and Nicotiana tabaccum (42), the lack of similarity at the translated protein level suggests that the specificity of that protein is fairly different from that in ACR. In summary, more research is needed in order to identify the homologous genes in plants as well as their physiological function.

Extensive research has been performed in order to elucidate the pathway for arsenate reduction to arsenite (14,43-45). However, much of this work has been performed in bacteria and yeast where some families of arsenate reductases (ArsC) have been identified (44). To our knowledge, those enzymes have not been reported in plants (42). However they may be used to model the mechanism of arsenate to arsenite reduction in plants. In any case, the moieties present in the enzymes, which are responsible for the arsenate reduction, include functional groups containing sulfur. After reduction, the resulting arsenite species are over again complexed by sulfur entities, which in plants might include glutathione related compounds such as phytochelatins, and protein residues. Some researchers have identified phytochelatins (which are glutathione related compounds) as important molecules possibly related to As resistance in plants (46). Moreover, Raab et al. (47) reported the extraction of As-phytochelatin complexes obtained from the arsenic tolerant plant $(H$. lanatus $)$ and the arsenic hyperaccumulator plant ( $P$. cretica). The data obtained in this research suggested that tumbleweed may also produce thiol related compounds to chelate and inactivate the absorbed arsenic.

Even when at this point tumbleweed cannot be considered arsenic hyperaccumulator, its tolerance to the arsenate levels used in this study indicate that this plant may assist in the revegetation of disturbed sites contaminated with arsenic at low levels. In addition, different strategies including genetic engineering and the use of chelating agents can be explored in order to improve arsenic uptake by this plant species. Recently, Dhankher et al. (48) have reported the over expression of two bacterial genes in Arabidopsis thaliana. By this manipulation, As translocation to the leaves has been improved. On the other hand, Pickering et al. (14) showed that mercaptosuccinate added to the growth media significantly improved As translocation in Indian mustard. This study showed that tumbleweed tolerate moderate amounts of $\mathrm{As}(\mathrm{V})$. In addition, the data provided by this research is important since few studies have been performed in desert plant species non-forming mycorrhizal association. S. kali is a Cd hyperaccumulator which can tolerate moderate amounts of As and thus is well suited for the remediation of mixed contaminant sites and it transforms $\mathrm{As}(\mathrm{V})$ to $\mathrm{As}(\mathrm{III})$.

Figure 1. (a) Expanded view of the XANES region from 11.87-11.89 keV showing the slight deviation in geometry of the $\mathrm{As}_{2} \mathrm{~S}_{3}$ and $\mathrm{As}(\mathrm{V})$ accumulated by tumbleweed plants. (b) Expanded view of the XANES region from 11.87-11.89 keV showing the slight deviation in geometry of the $\mathrm{As}_{2} \mathrm{~S}_{3}$ and $\mathrm{As}(\mathrm{III})$ accumulated by tumbleweed plants.

Figure 2. (a) Non phase and amplitude corrected Fourier transformed EXAFS of As(V) accumulated by tumbleweed roots, shoots, leaves, and $\mathrm{As}_{2} \mathrm{~S}_{3}$; (b) Non phase and amplitude corrected Fourier transformed EXAFS of As(III) accumulated by tumbleweed roots, shoots, leaves and $\mathrm{As}_{2} \mathrm{~S}_{3}$. 


\section{Supplementary Material}

Refer to Web version on PubMed Central for supplementary material.

\section{Acknowledgements}

The authors acknowledge financial support from the NIH (Grant S06GM8012-33), the SSRL/DOE funded Gateway Program and the UTEP's Center for Environmental Resource Management (CERM). The authors also thank the HBCU/MI ETC, which is funded by the DOE. Portions of this research were carried out at the Stanford Synchrotron Radiation Laboratory, a national user facility operated by Stanford University on behalf of the U.S. Department of Energy, Office of Basic Energy Sciences. The SSRL Structural Molecular Biology Program is supported by the Department of Energy, Office of Biological and Environmental Research, and by the National Institutes of Health, National Center for Research Resources, Biomedical Technology Program. Dr. Gardea-Torresdey acknowledges the Dudley family for the Endowed Research Professorship in Chemistry and the STAR Fellowship. Guadalupe de la Rosa thanks CONACyT (Consejo Nacional de Ciencia y Tecnología, Mexico, grant 131996), and the Universidad de Guanajuato.

\section{References}

1. Bothe JV, Brown PW. Arsenic immobilization by calcium arsenate formation. Environ Sci Technol 1999;33:3806-3811.

2. Mulligan CN, Yong RN, Gibbs BF. Remediation technologies for metal-contaminated soils and groundwater: an evaluation. Eng Geol 2001;60:193-207.

3. Barceló J, Poschenrieder CH. Phytoremediation: Principles and perspectives. Contrib Sci 003;2:333344.

4. Caravaca F, Alguacil MM, Figueroa D, Barea JM, Roldán A. Re-establishment of Retama sphaerocarpa as a target species for reclamation of soil physical and biological properties in a semiarid Mediterranean land. Forest Ecol Manag 2003;182:49-58.

5. Knudson JA, Meikle T, DeLuca THJ. Role of Mycorrhizal fungi and phosphorus in the arsenic tolerance of Basin Wildrye. Environ Qual 2003;32:2001-2006.

6. Aldrich MV, Gardea-Torresdey JL, Peralta-Videa JR, Parsons JG. Uptake and reduction of Cr(VI) to Cr(III) by Mesquite (Prosopis spp.): Chromate-plant interaction in hydroponics and solid media studied using XAS. Environ Sci Technol 2003;37:1859- 1864. [PubMed: 12775058]

7. Marchiol L, Assolari S, Sacco P, Zerbi G. Phytoextraction of heavy metals by canola (Brassica napus) and radish (Raphanus sativus) grown on multicontaminated soil. Environ Pollut 2004;132:2127. [PubMed: 15276270]

8. Fayiga AO, Ma LQ, Cao X, Rathinasabapathi B. Effects of heavy metals on growth and arsenic accumulation in the arsenic hyperaccumulator Pteris vittata L. Environ Pollut 2004;132:289-296. [PubMed: 15312941]

9. De la Rosa G, Peralta-Videa JR, Montes M, Parsons JG, Cano-Aguilera I, Gardea-Torresdey JL. Cadmium uptake and translocation in tumbleweed (Salsola kali), a potential Cd-hyperaccumulator desert plant species: ICP/OES and XAS studies. Chemosphere 2004;55:1159-1168. [PubMed: 15081756]

10. Gardea-Torresdey JL, Peralta-Videa JR, Montes M, de la Rosa G, Corral-Diaz B. Bioaccumulation of cadmium, chromium and copper by Convolvulus arvensis L.: impact on plant growth and uptake of nutritional elements. Bioresour Technol 2004;92:229-235. [PubMed: 14766155]

11. Sharma NC, Gardea-Torresdey JL, Parsons JG, Sahi SV. Chemical speciation and cellular deposition of lead in Sesbania drummondii. Environ Toxicol Chem 2004;23:2068-2073. [PubMed: 15378980]

12. Gardea-Torresdey JL, Peralta-Videa JR, de la Rosa G, Parsons JG. Coord Chem Rev 2005;249:17971810.

13. Gonzalez-Chavez C, Harris PJ, Dodd J, Meharg AA. Arsenate resistance in the ericoid mycorrhizal fungus Hymenoscyphus ericae. New Phytol 2002;155:163-171.

14. Pickering IJ, Prince RC, George MJ, Smith RD, George GN, Salt DE. Reduction and coordination of arsenic in Indian Mustard. Plant Physiol 2000;122:1171-1178. [PubMed: 10759512]

15. Salt DE, Prince RC, Pickering IJ. Chemical speciation of accumulated metals in plants: evidence from X-ray absorption spectroscopy. Microchem J 2002;71:255-259. 
16. Webb SM, Gaillard JF, Ma LQ, Tu C. XAS speciation of arsenic in a hyperaccumulating fern. Environ Sci Technol 2003;37:754-760. [PubMed: 12636275]

17. Zhang W, Cai Y, Downum KR, Ma LQ. Arsenic complexes in the arsenic hyperaccumulator Pteris vittata (Chinese brake fern). J Chromatogr A 2004;1043:249-254. [PubMed: 15330099]

18. Font R, Del Rio M, Vélez D, Montoro R, De Haro A. Sci Total Environ 2004;327:93-104. [PubMed: 15172574]

19. Paktunc D, Foster A, Heald S, Laflamme G. Speciation and characterization of arsenic in gold ores and cyanidation tailings using X-ray absorption spectroscopy. Geochim Cosmochim Acta 2004;68:969-983.

20. Szpunar J, McSheehy S, Polec K, Vacchina V, Mounicou S, Rodriguez I, Lobinski R. Gas and liquid chromatography with inductively coupled plasma mass spectrometry detection for environmental speciation analysis - advances and limitations. Spectrochim Acta 2000;55B:777-791.

21. Tu S, Ma LQ, MacDonald GE, Bondada B. Effects of arsenic species and phosphorus on arsenic absorption, arsenate reduction and thiol formation in excised parts of Pteris vittata L. Environ Exp Bot 2004;51:121-131.

22. Allen EB, Allen MF. Facilitation of succession by the nonmycotrophic colonizer Salsola kali (Chenopodiaceae) on a harsh site: Effects of Mycorrhizal fungi. Am J Bot 1988;75:257-266.

23. Peralta JR, Gardea-Torresdey JL, Tiemman KJ, Gomez E, Arteaga S, Rascon E, Parsons J. Uptake and effect of five heavy metals on seed germination and plant growth in alfalfa (Medicago sativa). Bull Environ Contam Toxicol 2001;66:727-734. [PubMed: 11353374]

24. Paliouris G, Hutchinson TC. Arsenic, cobalt and nickel tolerance in two populations of Silene vulgaris (Moench) Garcke from Ontario, Canada. New Phytol 1991;117:449-459.

25. Kingston, HM.; Jassie, LB. Am Chem Soc. Washington, D.C.: 1988. ACS Professional Reference Book Series.

26. Marin AR, Masscheleyn PH, Patrick WH. The influence of chemical form and concentration of arsenic on rice growth and tissue arsenic concentration. Plant Soil 1992;139:175-183.

27. U.S. EPA. U.S. Environmental Protection Agency. Office of Research and Development. Washington, D.C.: Determination of metals and trace elements in water and wastes by inductively coupled plasma-atomic emission spectrometry; p. 31-83.EPA (series 200). EPA/600/4-91/0101991

28. Ressler T. WinXAS: a program for X-ray absorption spectroscopy data analysis under MS-Windows. J Synchrotron Radiat 1998;5:112-118. [PubMed: 16687812]

29. U.S. EPA. U.S. Environmental Protection Agency. Soil screening guidance: technological background document. Office of emergency and remedial response. Washington, D.C.: 1996. EPA/ 540/R-95/128

30. Calabrese EJ, Baldwin LA. The hormetic dose-response model is more common than the threshold model in toxicology. Toxicol Sci 2003;71:246-250. [PubMed: 12563110]

31. Tu C, Ma LQ, Bondada B. Arsenic accumulation in the hyperaccumulator Chinese Brake and its utilization potential for phytoremediation. J Environ Qual 2002;31:1671-1675. [PubMed: 12371185]

32. Carbonell-Barrachina AA, Aarabi MA, DeLaune RD, Gambrell RP, Patrick WH. The influence of arsenic chemical form and concentration on Spartina patens and Spartina alterniflora growth and tissue arsenic concentration. Plant Soil 1998;198:33-43.

33. Aldrich, MV. PhD dissertation. University of Texas at El Paso; El Paso, Texas: 2004. Toxicity and accumulation of chromium, lead, copper, and arsenic in mesquite (Prosopis spp.).

34. Kissell, MA.; Fuhrmann, M.; Reeder, RJ. Uptake of arsenic by Pteris cretica: in situ XANES study of living plants. Abstracts of papers, 226th ACS National Meeting; New York, NY, USA. 2003.

35. Macnair MR, Cumbes Q. Evidence that arsenic tolerance in Holcul lanatus L. is caused by an altered phosphate uptake system. New Phytol 1987;107:387-394.

36. Wang J, Zhao FJ, Meharg AA, Raab A, Feldman J, McGrath SP. Mechanisms of arsenic hyperaccumulation in Pteris vittata. Uptake kinetics, interactions with phosphate, and arsenic speciation. Plant Physiol 2002;130:1552-1561. [PubMed: 12428020]

37. Patra M, Bhowmil N, Bandopadhyay B, Sharma A. Comparison of mercury, lead and arsenic with respect to genotoxic effects on plant systems and the development of genetic tolerance. Environ Exp Bot 2004;52:199-223. 
38. Baird, C. Environmental Chemistry. 2. W.H. Freeman and Company; New York, U.S.A: 2000.

39. Suckchawalit R, Prapagdee B, Chareonlap N, Vattanaviboon P, Monfkolsuk S. Protection of Xanthomonas against arsenic toxicity involves the peroxide-sensing transcription regulator OxyR. Res Microbiol 2005;156:30-34. [PubMed: 15636745]

40. Ghosh M, Shen J, Rosen BP. Pathways of As(III) detoxification in Saccharomyces cerevisiae. Proc Natl Acad Sci 1999;96:5001-5006. [PubMed: 10220408]

41. Liu Z, Shen J, Carbrey JM, Mukhopahyay R, Agre P, Rosen BP. Arsenite transport by mammalian aquaglyceroporins AQP7 and AQP9. Proc Natl Acad Sci 2002;99:6053-6058. [PubMed: 11972053]

42. ExPaSy Proteomics Server. 2004. http://www.expasy.org

43. Delnomdedieu M, Basti MM, Otvos JD, Thomas DJ. Reduction and binding of arsenate and dimethylarsinate by glutathione: a magnetic resonance study. Chemico-Biol Interact 1994;90:139_ 155.

44. Martin P, DeMel S, Shi J, Gladysheva T, Gatti DL, Rosen BP, Edwards BFP. Insights into the structure, solvation, and mechanism of ArsC arsenate reductase, a novel arsenic detoxification enzyme. Structure 2001;9:1071-1081. [PubMed: 11709171]

45. Messens J, Martins JC, VanBelle K, Brosens E, Desmyter A, DeGieter M, Wieruszeski JM, Willem R, Wyns L, Zegers I. All intermediates of the arsenate reductase mechanism, including an intramolecular dynamic disulfide cascade. Proc Natl Acad Sci 2002;99:8506-8511. [PubMed: 12072565]

46. Hartley-Whitaker J, Ainsworth G, Vooijs R, Bookum WT, Schat H, Meharg AA. Phytochelatins are involved in differential arsenate tolerance in Holcus lanatus. Plant Physiol 2001;126:299-306. [PubMed: 11351093]

47. Raab A, Feldman J, Meharg AA. The nature of arsenic - phytochelatin complexes in Holcus lanatus and Pteris cretica. Plant Physiol 2004;134:1113-1122. [PubMed: 15001701]

48. Dhankher OP, Li Y, Rosen BP, Shi J, Salt D, Senecoff JF, Sashti NA, Meagher RB. Engineered tolerance and hyperaccumulation of arsenic in plants by combining arsenate reductase and $\mathrm{g}$ glutamylcysteine synthetase expression. Nature Biotechnol 2002;20:1140-1145. [PubMed: 12368812] 

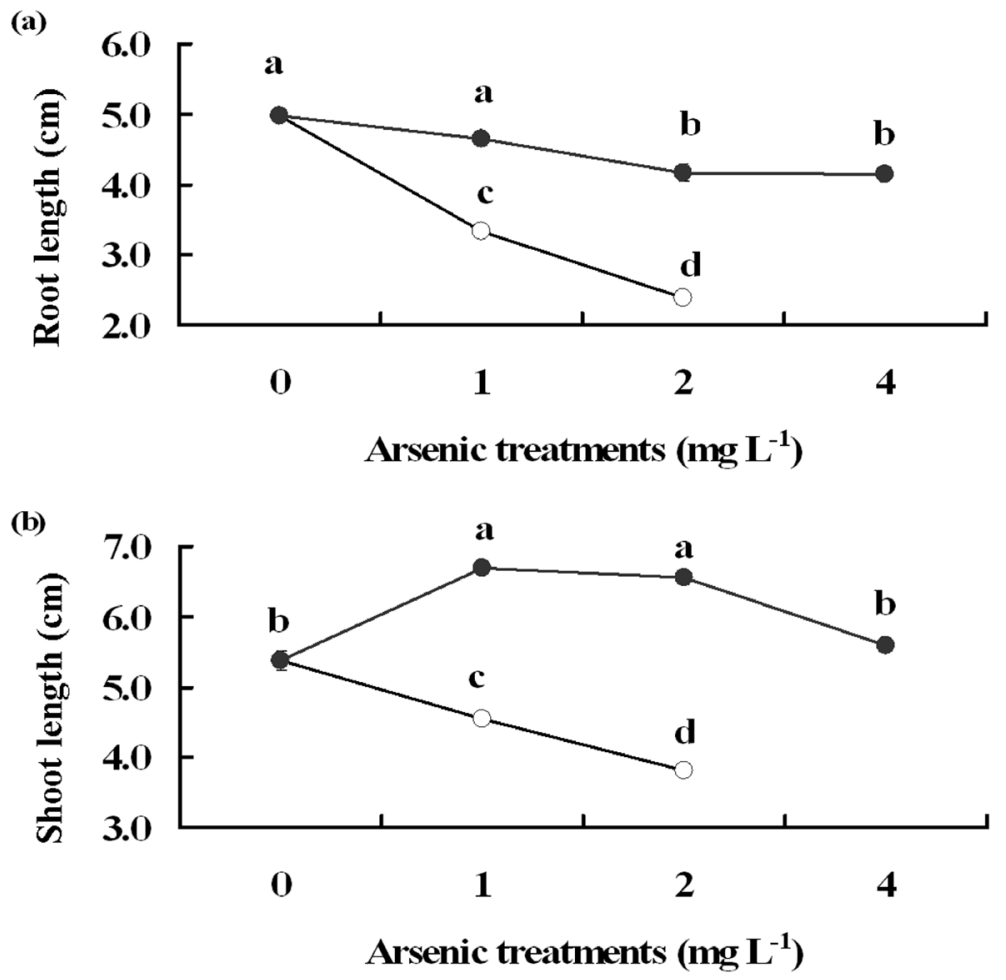

Figure 1.

Root (a) and shoot (b) length of tumbleweed plants treated with different concentrations of As (III) (O), and As(V) $(\bullet)$. Data are mean of three replicates of 10 plants each \pm S.E. Different letters indicate statistically significant differences between treatments according to Tukey's HSD test at $\mathrm{P}<0.05$. 
(a)

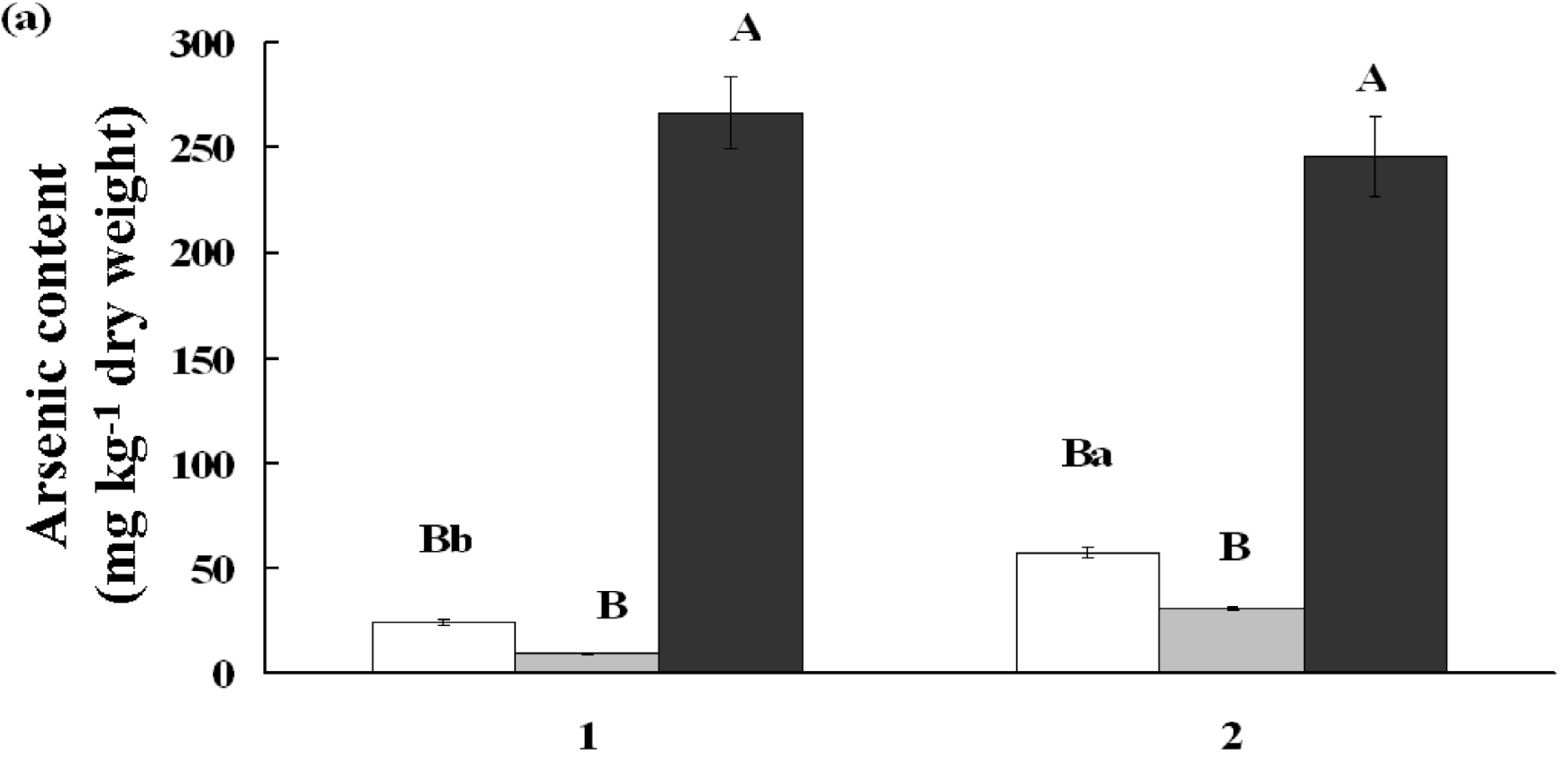

Arsenic (III) treatments (mg $\mathbf{L}^{-1}$ )

(b)

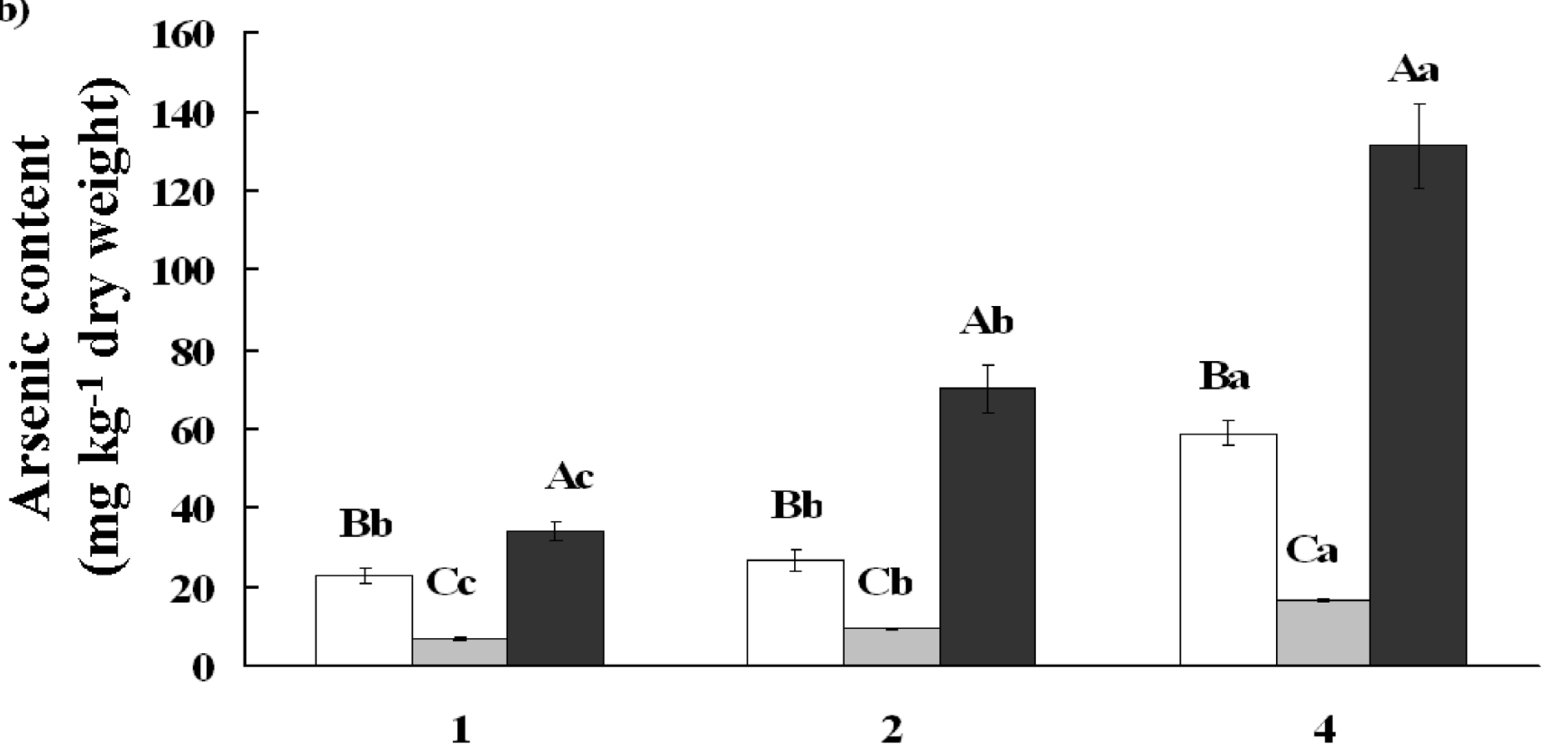

Arsenic (V) treatments ( $\left.m g L^{-1}\right)$

Figure 2.

Arsenic content in Leaves $\square$, Stems $\square$, and Roots $\square$ of tumbleweed plants grown for 15 days in agar media with different concentrations of (a) As(III); and (b) As(V). Data are mean of three replicates $\pm \mathrm{S}$.E. Lowercase letters indicate statistically significant differences in As content in the same tissue and different treatments; Uppercase letters indicate statistically significant differences in As content between tissues of the same treatment at $\mathrm{P}<0.05$. 

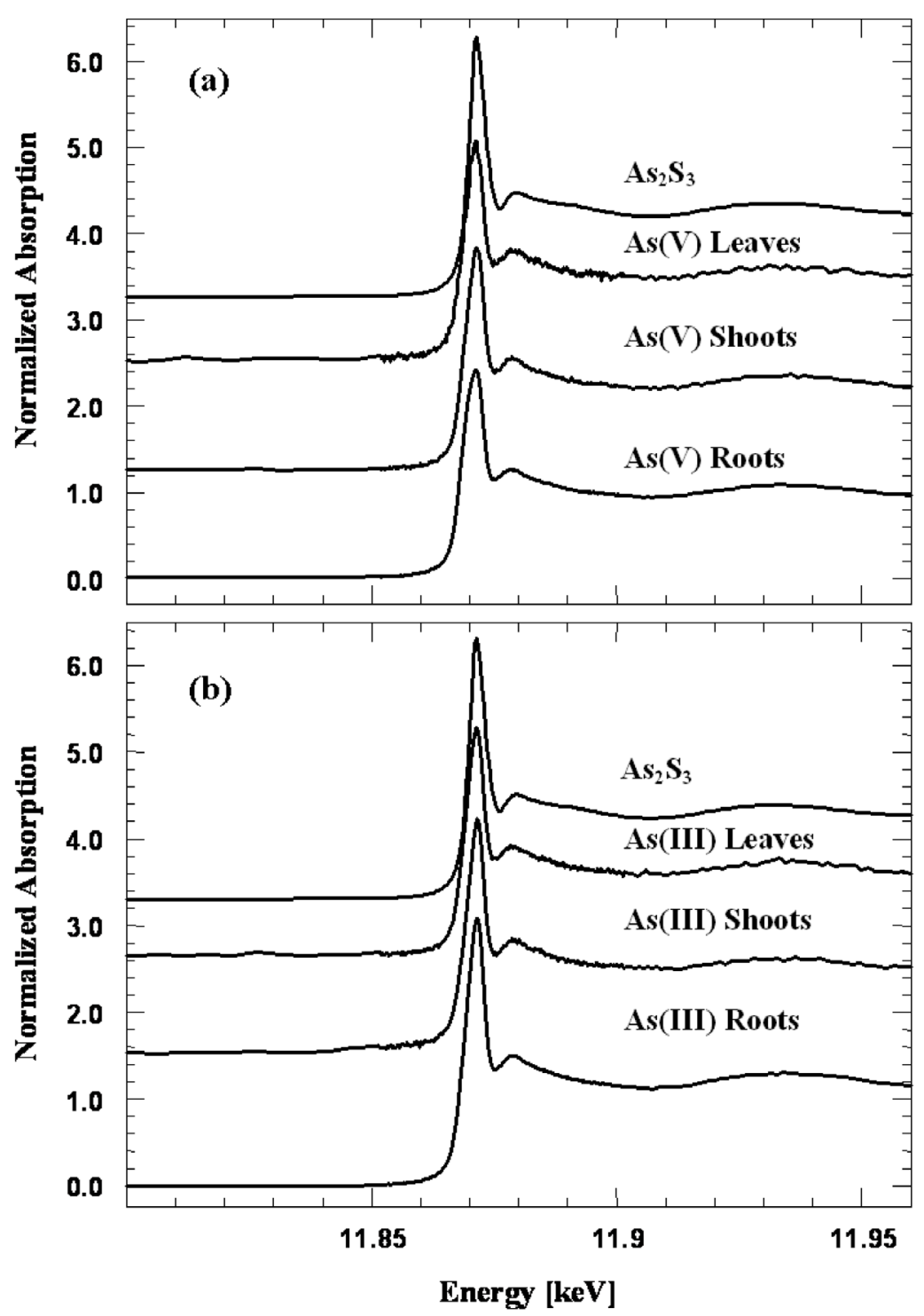

Figure 3.

(a) XANES of the $\mathrm{As}_{2} \mathrm{~S}_{3}$ model compound and of the $\mathrm{As}(\mathrm{V})$ accumulated by tumbleweed in roots, shoots, leaves, (b) XANES of the $\mathrm{As}_{2} \mathrm{~S}_{3}$ model compound and of As(III) accumulated by tumbleweed in roots, shoots, leaves. 
Table 1

Phosphorous concentrations in tumbleweed plants grown for 15 days in a modified Hoagland nutrient medium (23) containing either As(III) or As(V). One-way ANOVA and Tukey's test were used to separate averages. Lowercase letters indicate significant differences $(\mathrm{P}<0.05)$ in $\mathrm{P}$ content between control plants and those treated with As(III). Uppercase letters indicate significant differences $(\mathrm{P}<0.05)$ in $\mathrm{P}$ content between control plants and those treated with As(V). Data are mean \pm SE. (--) not determined.

\begin{tabular}{|c|c|c|c|c|}
\hline \multirow{2}{*}{$\begin{array}{l}\text { Treatments (mg L }{ }^{-1} \\
\text { As) }\end{array}$} & \multirow[t]{2}{*}{ As species } & \multicolumn{3}{|c|}{$\operatorname{mg} P(\operatorname{kg~d.wt})^{-1}$} \\
\hline & & Roots & stems & leaves \\
\hline 0 & - & $11869 \pm 823_{\mathrm{aA}}$ & $8272 \pm 280$ & $8222 \pm 490_{\mathbf{A}}$ \\
\hline \multirow[t]{2}{*}{1} & As(III) & $8320 \pm 147_{b}$ & $7440 \pm 440$ & $7060 \pm 100$ \\
\hline & $\operatorname{As}(\mathrm{V})$ & $8453 \pm 220_{\mathbf{B}}$ & $7380 \pm 310$ & $7160 \pm 260_{\mathrm{AB}}$ \\
\hline \multirow[t]{2}{*}{2} & As(III) & $6900 \pm 310_{b}$ & $7130 \pm 310$ & $7200 \pm 230$ \\
\hline & $\mathrm{As}(\mathrm{V})$ & $7830 \pm 77_{\mathbf{B}}$ & $7610 \pm 196$ & $6770 \pm 55_{\mathbf{B}}$ \\
\hline \multirow[t]{2}{*}{4} & As(III) & -- & -- & -- \\
\hline & $\mathrm{As}(\mathrm{V})$ & $6380 \pm 420_{\mathbf{B}}$ & $7760 \pm 162$ & $6520 \pm 67_{\mathbf{B}}$ \\
\hline
\end{tabular}


Table 2

Pearson correlation coefficients for arsenic and phosphorous content in tumbleweed plants.

\begin{tabular}{llll}
\hline Plant tissue & As treatment & Pearson correlation coefficient & Significance \\
\hline Roots & As(III) & $-0.865^{* *}$ & 0.003 \\
& As(V) & $-0.871^{* *}$ & 0.000 \\
Stems & As(III) & -0.621 & 0.074 \\
& As(V) & -0.329 & 0.296 \\
Leaves & As(III) & -0.564 & 0.114 \\
& As(V) & $-0.739^{* *}$ & 0.006 \\
\hline
\end{tabular}

** Correlation is significant at the 0.01 level (2-tailed) 
Table 3

EXAFS fittings of the As present in roots, shoots, and leaves of tumbleweed plants, the As found in the agar, and the As model compounds.

\begin{tabular}{|c|c|c|c|c|}
\hline Sample & Bond & $\mathbf{N}$ & $\mathbf{R}(\AA)$ & $\sigma^{2}\left(\AA^{2}\right)$ \\
\hline As(V) Roots & As-S & 3.0 & 2.24 & 0.0030 \\
\hline As(V) Shoots & As-S & 2.0 & 2.26 & 0.0043 \\
\hline As(V) Leaves & As-S & 3.0 & 2.26 & 0.0030 \\
\hline As(m) Roots & As-S & 3.0 & 2.24 & 0.0055 \\
\hline As(m) Shoots & As-S & 2.91 & 2.26 & 0.0045 \\
\hline As(in) Leaves & As-S & 2.8 & 2.25 & 0.0044 \\
\hline $\mathrm{As}_{2} \mathrm{O}_{3}$ & As-O & 3.0 & 1.79 & 0.0026 \\
\hline $\mathrm{As}_{2} \mathrm{O}_{5}$ & As-O & 3.9 & 1.67 & 0.0015 \\
\hline $\mathrm{As}_{2} \mathrm{~S}_{3}$ & As-S & 2.99 & 2.27 & 0.0015 \\
\hline $\mathrm{NaHAsO}_{4}$ & As-O & 4.1 & 1.68 & 0.0034 \\
\hline As(V) Agar & As-O & 4.0 & 1.68 & 0.0040 \\
\hline As(m) Agar & As-O & 2.9 & 1.78 & 0.0015 \\
\hline
\end{tabular}

Note: $\mathrm{N}$ is the coordination number, $\mathrm{R}$ is the interatomic distance give in angstroms, $\sigma^{2}$ is the Debye-Waller factor. 